\title{
Enantioselective total syntheses of (+)- and (-)-ottelione $A$ and (+)- and (-)-ottelione B. Absolute configuration of the novel, biologically active natural products
}

\author{
Goverdhan Mehta* and Kabirul Islam \\ Department of Organic Chemistry, Indian Institute of Science, Bangalore 560 012, India
}

\begin{abstract}
Following our recent total synthesis of the biologically potent natural products otteliones A and B in racemic form, we have now accomplished the total synthesis of both the enantiomers of otteliones A and B through an enantiodivergent strategy emanating from the readily available Diels-Alder adduct of cyclopentadiene and $p$-benzoquinone. These endeavors have led to the elucidation of the absolute configuration of naturally occurring otteliones A and B.
\end{abstract}

Otteliones A and B are two structurally novel natural products, first reported in 1998 from the widely occurring freshwater plant ottelia alismoides, which extensively lines irrigation canals and rice fields in south east Asia and Africa. ${ }^{1 a}$ Collaborative efforts between the US and Egyptian scientists ${ }^{1 \mathrm{a}}$ and subsequent reinvestigations at Rhone-Poulenc Rorer (now Aventis) ${ }^{1 \mathrm{~b}}$ have led to the establishment of structures $\mathbf{1}$ and $\mathbf{2}$ for ottelione A (RPR 112378) ${ }^{1 \mathrm{~b}}$ and $\mathrm{B}$, respectively, based mainly on high field ${ }^{1} \mathrm{H}$ NMR studies. Otteliones exhibit quite a remarkable biological activity profile. While the Chinese scientists ${ }^{2 a}$ have reported on the anti-tuberculor effect of the extract of ottelia alismoides rich in otteliones, screening against a panel of 60 human cancer cell lines at the National Cancer Institute has revealed cytotoxicity of ottelione A at nM-pM levels. ${ }^{1 \mathrm{a}, 2 \mathrm{~b}}$ More recently, it has been shown that ottelione $\mathrm{A}$ is an efficient inhibitor of tubulin polymerization $\left(\mathrm{IC}_{50}=1.2\right.$ $\mu \mathrm{M})$ and is able to disassemble preformed microtubules in a manner reminiscent of colchicine and vinblastin. ${ }^{1 \mathrm{~b}}$ These promising biological activity attributes, the presence of an unusual and reactive 4-methylenecyclohex-2enone moiety and the biogenetically interesting framework make otteliones attractive synthetic targets. ${ }^{3,4}$ Several synthetic studies directed towards otteliones have appeared in the literature ${ }^{3}$ and we have recently described the first total synthesis ${ }^{4}$ of ottelione A $\mathbf{1}$ and ottelione B $\mathbf{2}$ in racemic form, which also unambiguously settled their structures. However, the

\footnotetext{
* Corresponding author.
}

absolute configuration of otteliones has not yet been determined though this is an important requirement vis-à-vis their biological activity profile. This could possibly be due to the inability to apply directly chirooptical probes to this system. We therefore decided to settle the absolute configuration of otteliones through enantioselective synthesis and considering the lack of consistency ${ }^{5}$ regarding the specific rotation of the naturally occurring otteliones, it was decided to undertake the total synthesis of both the enantiomers. These studies have led to the establishment of the absolute configuration of ottelione $\mathrm{A}$ as (+)-1 and ottelione $\mathrm{B}$ as $(-)-2$ and these results form the subject matter of this letter.

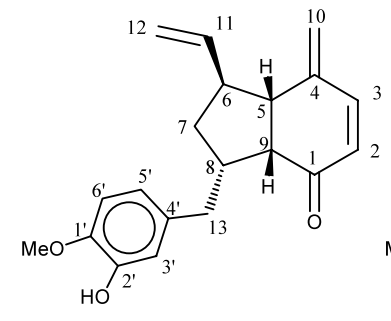

$(+)-1(5 S, 6 S, 8 S, 9 R)$

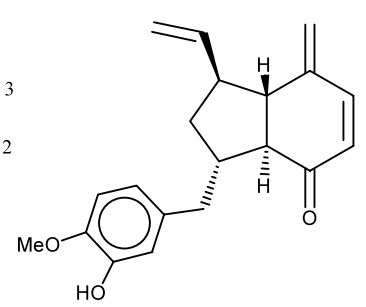

$(-)-2(5 S, 6 S, 8 S, 9 S)$
Our total synthesis of rac-otteliones had commenced from the readily available Diels-Alder adduct $3^{6}$ of cyclopentadiene and $p$-benzoquinone and involved the terminal olefin $\mathbf{4}$ as an intermediate. ${ }^{4}$ In order to achieve the synthesis of both (+)- and (-)-otteliones A and $\mathrm{B}$, access to both the enantiomers of $\mathbf{4}$ from $\mathbf{3}$ was 
required through an enantiodivergent route. This was accomplished employing enzymatic desymmetrization as the key step. Adduct 3 on LAH reduction furnished hydroxy-ketone $\mathbf{5}$ which was oxidized with PCC to the dione 6 (Scheme 1). ${ }^{7}$ DIBAL-H reduction of 6 was stereoselective and led to the endo,endo-diol 7. The meso-diol 7 was subjected to lipase catalysed transesterification, as described earlier by Ogaswara et al. ${ }^{8}$ to furnish enantiopure monoacetate (+)-8 (Scheme 1). TBS-protection of the hydroxyl group in (+)-8 gave $(+)-\mathbf{9}$ and the acetate group was hydrolyzed to $(-)-\mathbf{1 0}$ and further oxidized to the ketone (+)-11. Lombardo methylation ${ }^{9}$ of (+)-11 led to (+)-12, and TBS deprotection furnished enantiomerically pure (+)-4, the key starting material for our ottelione synthesis. ${ }^{10}$

The hydroxy-methylene compound (+)-4 was elaborated to ottelione A essentially following the route outlined by $\mathrm{us}^{4}$ for the racemic synthesis of otteliones and is schematically represented in Scheme 2. Successful implementation of Scheme 2 led to (+)-ottelione A 1 which had a specific rotation of $+19.2\left(c 0.52, \mathrm{CHCl}_{3}\right){ }^{5}$ The observed rotation of our synthetic ottelione A was a good match with that reported for the natural product. We also compared the CD spectrum ${ }^{11}$ of the synthetic ottelione A with that of the natural product and found them to be identical, thus establishing the absolute configuration of ottelione $\mathrm{A}$ as $(+)-1 .^{11,12}$

Otteliones A and B have a diastereomeric relationship with respect to the $\mathrm{C} 9$ stereogenic center and we have shown $^{4}$ that the former can be isomerized to the latter
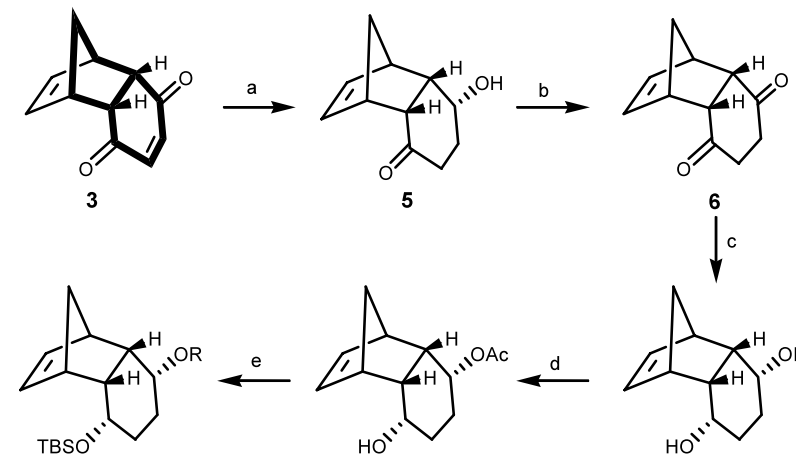

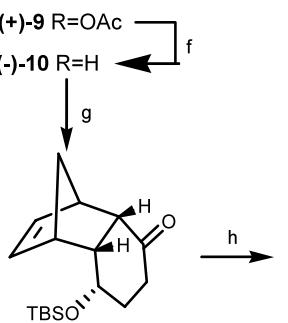

(+)-11

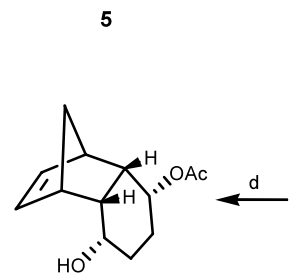

$(+)-8$

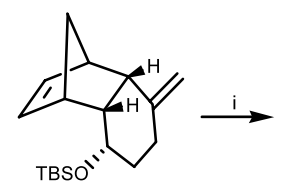

$(+)-12$

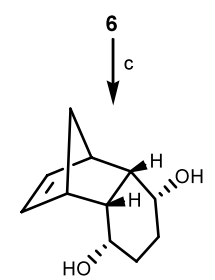

7

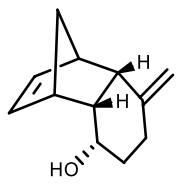

(+)-4
Scheme 1. Reagents and conditions: (a) $\mathrm{LiAlH}_{4}$, ether, $0^{\circ} \mathrm{C}$, $78 \%$; (b) PCC, DCM, $0^{\circ} \mathrm{C}, 82 \%$; (c) DIBAL-H, DCM, $-78^{\circ} \mathrm{C}$, $83 \%$; (d) Lipase PS (amano), vinyl acetate, THF, rt 85\%; (e) TBSCl, imidazole, DMAP, DCM, $90 \%$; (f) $\mathrm{K}_{2} \mathrm{CO}_{3}, \mathrm{MeOH}$, $0^{\circ} \mathrm{C}, 80 \%$; (g) PDC, DCM, rt $86 \%$; (h) $\mathrm{Zn}-\mathrm{TiCl}_{4}-\mathrm{CH}_{2} \mathrm{Br}_{2}$, DCM, $0^{\circ} \mathrm{C}, 79 \%$; (i) TBAF, THF, rt $88 \%$.

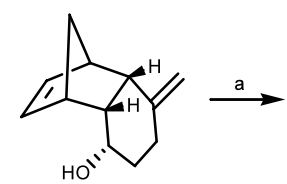

$(+)-4$

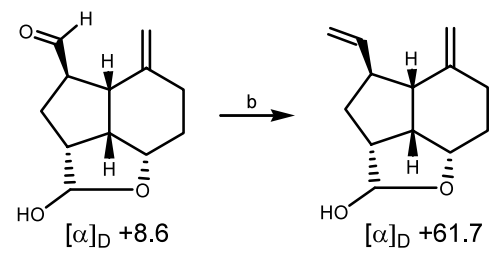

$[\alpha]_{D}+61.7$<smiles>C=C[C@H]1C[C@H](Cc2ccc(C)c(O)c2)[C@@]2(C)[C@@H](O)CCC(=C)[C@H]12</smiles>

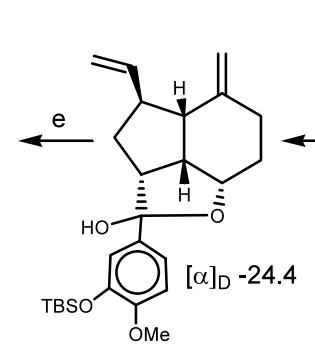

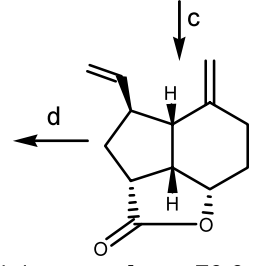

$[\alpha]_{D}+70.3$

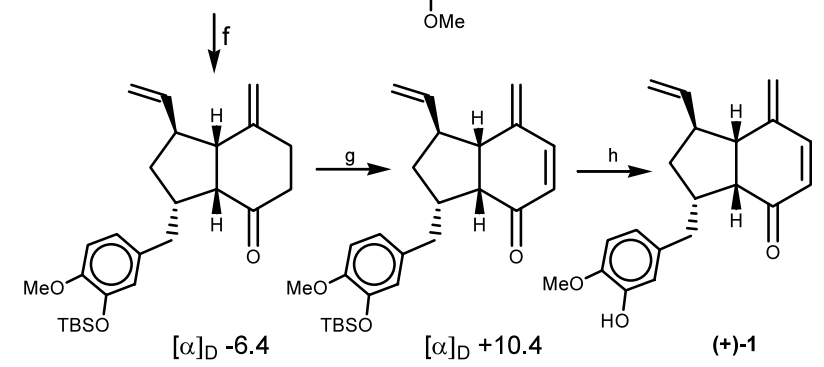

Scheme 2. Reagents and conditions: (a) i. $\mathrm{O}_{3}, \mathrm{MeOH},-78^{\circ} \mathrm{C}$, ii. $\mathrm{Me}_{2} \mathrm{~S}$, rt $72 \%$; (b) $\mathrm{Ph}_{3} \mathrm{PCH}_{3}{ }^{+} \mathrm{I}^{-},{ }^{n} \mathrm{BuLi}$, THF, $0^{\circ} \mathrm{C}, 86 \%$; (c) PCC, DCM, $0^{\circ} \mathrm{C}, \quad 90 \%$; (d) 4-bromo-1-methoxy-2-(tertbutyldimethylsiloxy)benzene, ${ }^{n} \mathrm{BuLi}$, THF, $-78^{\circ} \mathrm{C}-\mathrm{rt}, 88 \%$; (e) Li, liq. $\mathrm{NH}_{3}, \mathrm{THF},-33^{\circ} \mathrm{C}, 65 \%$; (f) $\mathrm{PCC}, \mathrm{DCM}, 0^{\circ} \mathrm{C}, 87 \%$; (g) i. LHMDS, $\mathrm{PhSeCl}$, THF, $-78^{\circ} \mathrm{C}$; ii. $30 \% \mathrm{H}_{2} \mathrm{O}_{2}$, DCM, $0^{\circ} \mathrm{C}, 70 \%$ (two steps); (h) TBAF, THF, $0^{\circ} \mathrm{C}, 72 \%$.

on exposure to base. Consequently, synthetic (+)-ottelione $\mathrm{A} \mathbf{1}$ on treatment with $\mathrm{DBU}$ resulted in $\mathrm{C} 9$ epimerization to furnish (-)-ottelione B 2 having a specific rotation of $-250\left(c 0.24, \mathrm{CHCl}_{3}\right)$ similar to that reported $^{5,11}$ for ottelione $\mathrm{B}$ and led to confirmation of the absolute configuration (-)-2 for the natural product (Scheme 3).

Initially, not having any inkling of the absolute configuration of otteliones and also in the backdrop of conflicting information ${ }^{5}$ about the specific rotation of the natural products, we decided to undertake simultaneously the synthesis of both the enantiomers of otteliones. Consequently, the starting Diels-Alder adduct 3 was elaborated to the key intermediate (-)-4 in enantiomerically pure form ${ }^{10}$ through an adaptation of an earlier described procedure (Scheme 4). ${ }^{8}$

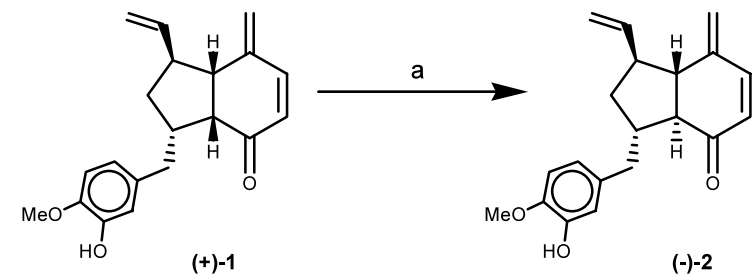

Scheme 3. Reagents and conditions: (a) DBU, benzene, $65^{\circ} \mathrm{C}$, $83 \%$. 
The hydroxy-acetate (+)-8 was oxidized to the acetoxyketone (-)-13 and Lombardo methylenation ${ }^{9}$ led to the terminal olefin (+)-14 (Scheme 4). Acetate deprotection in 14 delivered the desired key intermediate $(-)-4 .{ }^{10}$ Following the synthetic sequence outlined in Scheme 2

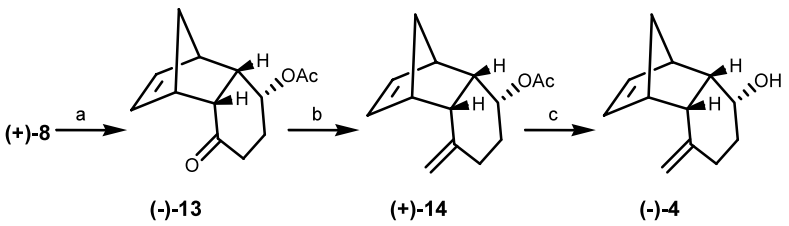

Scheme 4. Reagents and conditions: (a) PDC, DCM, $0^{\circ} \mathrm{C}$, $80 \%$; (b) $\mathrm{Zn}-\mathrm{TiCl}_{4}-\mathrm{CH}_{2} \mathrm{Br}_{2}, \mathrm{DCM}, 0^{\circ} \mathrm{C}, 76 \%$; (c) $\mathrm{K}_{2} \mathrm{CO}_{3}$, $\mathrm{MeOH}, 0^{\circ} \mathrm{C}$, quant.

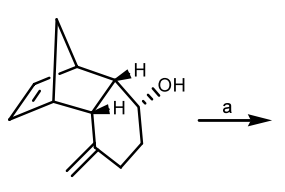

$(-)-4$<smiles>C=C[C@H]1C[C@H](Cc2ccc(OC)c(OC(C)(C)C)c2)[C@H]2[C@@H](O)CCC(=C)[C@H]12</smiles>

$[\alpha]_{D}-30.8$

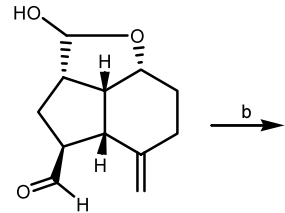

$[\alpha]_{D}-9.9$

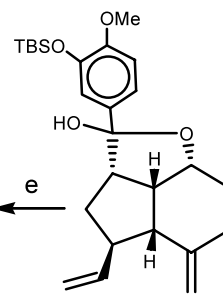

$[\alpha]_{D}+25.0$

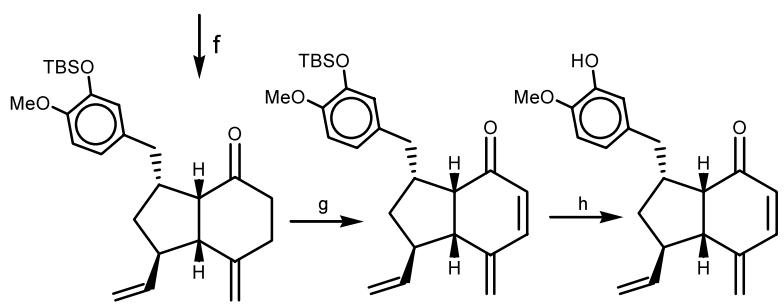

$[\alpha]_{D}+7.8$

$[\alpha]_{D}-10.9$

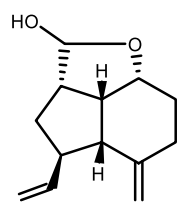

$[\alpha]_{D}-62.2$
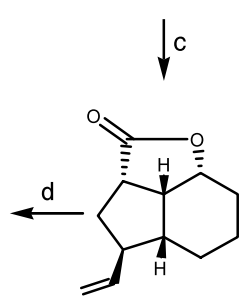

$[\alpha]_{D}-72.3$
Scheme 5. Reagents and conditions: (a) i. $\mathrm{O}_{3}, \mathrm{MeOH},-78^{\circ} \mathrm{C}$, ii. $\mathrm{Me}_{2} \mathrm{~S}, \mathrm{rt} \mathrm{70} \%$; (b) $\mathrm{Ph}_{3} \mathrm{PCH}_{3}{ }^{+} \mathrm{I}^{-},{ }^{n} \mathrm{BuLi}, \mathrm{THF}, 0^{\circ} \mathrm{C}, 85 \%$; (c) PCC, DCM, $0^{\circ} \mathrm{C}$, 91\%; (d) 4-bromo-1-methoxy-2-(tertbutyldimethylsiloxy)benzene, ${ }^{n} \mathrm{BuLi}$, THF, $-78^{\circ} \mathrm{C}-\mathrm{rt}, 87 \%$; (e) $\mathrm{Li}$, liq. $\mathrm{NH}_{3}, \mathrm{THF},-33^{\circ} \mathrm{C}, 85^{\circ}$; (f) $\mathrm{PCC}, \mathrm{DCM}, 0^{\circ} \mathrm{C}, 86 \%$; (g) i. LHMDS, $\mathrm{PhSeCl}, \mathrm{THF},-78^{\circ} \mathrm{C}$; ii. $30 \% \mathrm{H}_{2} \mathrm{O}_{2}, \mathrm{DCM}$, $0^{\circ} \mathrm{C}, 68 \%$ (two steps); (h) TBAF, THF, $0^{\circ} \mathrm{C}, 77 \%$.

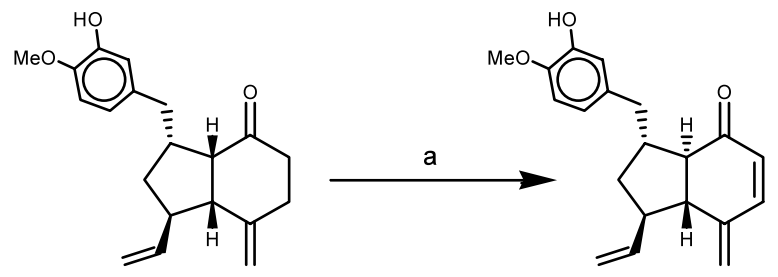

Scheme 6. Reagents and conditions: (a) DBU, benzene, $65^{\circ} \mathrm{C}$, $81 \%$. for the synthesis of (+)-ottelione A 1, (-)-4 was elaborated to (-)-ottelione A 1 (ent-ottelione A), $[\alpha]_{\mathrm{D}}-17(c$ $\left.0.4, \mathrm{CHCl}_{3}\right)$, Scheme 5. Finally, (-)-ottelione A 1 was epimerized with DBU to furnish (+)-ottelione B 2 (entottelione B), $[\alpha]_{\mathrm{D}}+246\left(c 0.4, \mathrm{CHCl}_{3}\right)$, Scheme $6 .{ }^{5}$

In short, we have outlined enantioselective syntheses of both the enantiomers of otteliones A and B from the Diels-Alder adduct 3 of cyclopentadiene and $p$-benzoquinone, following an enantiodivergent strategy. Our synthetic studies have established the absolute configuration of the naturally occurring otteliones $\mathrm{A}$ and $\mathrm{B}$ as $(+)-1$ and (-)-2, respectively.

\section{Acknowledgements}

K.I. thanks CSIR, India for the award of a research fellowship. This work was supported by the Chemical Biology Unit of JNCASR at the Indian Institute of Science, Bangalore. The lipase used in this study was a gift from Dr. Y. Hirose of Amano Pharmaceutical Co. Ltd, Japan.

\section{References}

1. (a) Ayyad, S. E. N.; Judd, A. S.; Shier, W. T.; Hoye, T. R. J. Org. Chem. 1998, 63, 8102; (b) Combeau, C.; Provost, J.; Lanceli, F.; Tournoux, Y.; Prod'homme, F.; Herman, F.; Lavelle, F.; Leboul, J.; Vuilhorgne, M. Mol. Pharm. 2000, 57, 553.

2. (a) Li, H.; Li, H.; Qu, X.; Shi, Y.; Guo, L.; Yuan, Z. Zhongguo Zhongyao Zazhi (Chin. J. Chin. Mat. Med.) 1995, 20, 128; (b) Leboul, J.; Prevost, J. French Patent WO96/00205, 1996 (Chem. Abstr. 1996, 124, 242296).

3. (a) Mehta, G.; Reddy, D. S. Chem. Commun. 1999, 2193; (b) Mehta, G.; Islam, K. Synlett 2000, 1473; (c) Trembleau, L.; Patiny, L.; Ghosez, L. Tetrahedron Lett. 2000, 41, 6377; (d) Mehta, G.; Islam, K. Org. Lett. 2002, 4, 2881; (e) Clive, D. L. J.; Fletcher, S. P. Chem. Commun. 2002, 1940; (f) Hoye, T. R., private communication.

4. Mehta, G.; Islam, K. Angew. Chem., Int. Ed. Engl. 2002, 41, 2396.

5. The two full papers ${ }^{1 \mathrm{a}, \mathrm{b}}$ dealing with the structure elucidation of otteliones do not report the specific rotation of these natural products. However, in response to our queries, Professor Hoye from the University of Minnesota $^{\text {la }}$ informed us that the two samples of ottelione $\mathrm{A}$ isolated by his group exhibited specific rotations of $+22\left(c 1.25, \mathrm{CDCl}_{3}\right)$ and $+14\left(c 0.87, \mathrm{CHCl}_{3}\right)$, respectively. On the other hand, Dr. H. Bouchard of Aventis (formerly RPR) $)^{1 \mathrm{~b}}$ informed us that their sample of ottelione $\mathrm{A}$ had a specific rotation of $-20.8\left(c 0.5, \mathrm{CH}_{2} \mathrm{Cl}_{2}\right)$. This was quite intriguing and spurred us to undertake the total synthesis of both the enantiomers of ottelione A. Professor Hoye has also informed us that a sample of ottelione B prepared by them had a rotation of -276 ( $c$ 2.0, $\mathrm{CHCl}_{3}$ ). We are most grateful to Professor Hoye and Dr. Bouchard for information regarding the rotations of otteliones. 
6. (a) Diels, O.; Blom, J. M.; Koll, W. Ann. 1925, 443, 247; (b) Cookson, R. C.; Crundwell, E.; Hill, R. R.; Hudec, J. J. Chem. Soc. 1964, 3062.

7. All compounds reported here were characterized through spectral comparison with their racemic counterparts prepared earlier by us. ${ }^{4}$

8. Konno, H.; Ogasawara, K. Synthesis 1999, 1135.

9. Lombardo, L. Tetrahedron Lett. 1982, 23, 4293.

10. Enantiomeric purity of the key intermediates $(+)-\mathbf{4},[\alpha]_{\mathrm{D}}$ $+93.7\left(c\right.$ 2.23, $\left.\mathrm{CHCl}_{3}\right)$ and $(-)-4,[\alpha]_{\mathrm{D}}-93.6$ (c 1.72, $\mathrm{CHCl}_{3}$ ) was determined through comparison of the specific rotation of the enzymatically desymmetrized common precursor $(+)-8,[\alpha]_{\mathrm{D}}+48.2\left(c 1.7, \mathrm{CHCl}_{3}\right)$, [lit. $[\alpha]_{\mathrm{D}}$ $\left.+44.2\left(c 1.6, \mathrm{CHCl}_{3}\right)\right]^{8}{ }^{8}>99 \%$ ee, with the literature values.

11. We greatly appreciate the free and helpful exchange of information with Professor Hoye that proved crucial in arriving at the correct absolute configuration of otteliones. Hoye's group has independently arrived at the same conclusion about the absolute configuration of otteliones on the basis of the Mosher ester studies with the alcohol derived from the reduction of ottelione A.

12. While we have unambiguously determined the absolute configuration of otteliones through enantiodivergent synthesis of both the enantiomers of otteliones A and B, the observed specific rotation of -20.8 by the Aventis group remains puzzling. One possible explanation could be that their sample of $(+)$-ottelione A was contaminated with ottelione $\mathrm{B},[\alpha]_{\mathrm{D}}-276$ having high negative (opposite) rotation and thus leading to the observation of net negative rotation for ottelione $\mathrm{A}$. 